\title{
Dopamine Receptor mRNA Expression in Human Striatum and Neocortex
}

\author{
James H. Meador-Woodruff, M.D., Scott P. Damask, B.S., Jingcheng Wang, M.S., \\ Vahram Haroutunian, Ph.D., Kenneth L. Davis, M.D., and Stanley J. Watson, Ph.D., M.D.
}

The distributions of the transcripts encoding the five dopamine receptors have been determined in the human striatum and selected regions of the neocortex. In the striatum significant levels of dopamine receptor expression are restricted to the $D_{1}, D_{2}$, and $D_{3}$ receptors. $D_{1}$ and $D_{2}$ receptor messenger ribonucleic acids ( $m R N A s)$ are homogeneously distributed throughout the caudate, putamen, and nucleus accumbens. $D_{3}$ receptor $m R N A$ is particularly enriched in the nucleus accumbens, with moderate levels in the ventral putamen. In the prefrontal cortex $D_{1}$ and $D_{4}$ receptor $m R N A$ s are the most abundant, although the other three transcripts are seen at lower levels.
A similar pattern is seen in the temporal neocortex. In the occipital cortex, $D_{1}$ receptor $m R N A$ is the most abundant, $D_{3}$ the rarest, while the other three transcripts are present at modest levels of expression. These data add to a growing understanding of the neuroanatomical distribution of these transcripts in the human brain. They are essential to understand in the context of the limbic circuitry of the brain, as new hypotheses of dysfunction of dopaminergic neurotransmission are advanced in psychiatry and as these receptor subtypes are targeted for development of novel pharmacological treatments. [Neuropsychopharmacology 15:17-29, 1996]
KEY WORDS: Dopamine receptors; Messenger RNA; Cerebral cortex; $D_{1}, D_{2}, D_{3}, D_{4}, D_{5}$; Caudate; Putamen; Nucleus accumbens

The cloning of five dopamine receptors (Grandy et al. 1989; Dearry et al. 1990; Giros et al. 1990; Sunahara et al. 1990, 1991; Zhou et al. 1990; Van Tol et al. 1991) has led to a new appreciation of the subtle complexity that multiple subtypes of receptors permit. A number of features ultimately determine the function of each receptor subtype, including pharmacology, second messenger coupling, and number of receptor molecules expressed. An important determinant in the expression of function of

From the Mental Health Research Institute and Department of Psychiatry (JHMW, SPD, JW, SJW); University of Michigan, Ann Arbor, Ml; and Department of Psychiatry (VH; KLD), Mount Sinai Medical Center, New York.

Address correspondence to: James H. Meador-Woodruff, M.D., Mental Health Research Institute, Department of Psychiatry, University of Michigan, 205 Zina Pitcher Place, Ann Arbor, Michigan 48109-0720.

Received May 25, 1995; revised July 20, 1995; accepted July 25, 1995. these receptors is neuroanatomical region-specific expression. Each of the dopamine receptors has been found to have a unique pattern of regional distribution in the brain. This, coupled with pharmacological features, determines the net result of receptor stimulation in a given brain structure. Accordingly, an understanding of the neurochemical anatomy of these receptors is of considerable interest.

Most of the understanding of the anatomical localization of the individual dopamine receptor subtypes has come from studies in rat brain, initially at the level of messenger ribonucleic acids (mRNAs) and more recently from work with specific antibodies to visualize receptor proteins in tissue sections (reviewed in Meador-Woodruff 1994 and Meador-Woodruff et al. 1994c, 1995). Detailed studies in the rat have revealed that $D_{1}$ and $D_{2}$ receptors, both at the mRNA and protein levels, are abundantly expressed in most of the traditional dopaminoceptive regions of the rat brain, including regions associated with motor, limbic, and neuroendocrine functions. The novel receptor subtypes, $D_{3}, D_{4}$, and $D_{5}$ have more restricted distributions. $D_{3}$ and $D_{4}$ 
receptors appear to be localized primarily in limbic regions of rat brain, with little to no expression in the dorsal striatum. The $\mathrm{D}_{5}$ receptor has a very limited distribution, primarily expressed in the diencephalon and hippocampus. These distinctive patterns of distribution suggest that certain receptor subtypes may be associated with specific dopaminergic functions. For example, striatal expression of $D_{1}$ and $D_{2}$ receptors suggests that these two subtypes may be the most significant in motor functions modulated by dopamine, whereas $D_{3}$ and $D_{4}$ receptors restricted to more limbic structures suggest that they may be of importance in our understanding of psychiatric illnesses.

Despite the rather detailed understanding of the neuroanatomy of these receptors in the rat brain, relatively little is known about their localization in the human brain. In this study, we report our findings on the localization of the transcripts for all five dopamine receptors in the human striatum and selected regions of cortex, and we summarize the current state of understanding of the distribution of these receptors throughout the entire human brain.

\section{METHODS}

Postmortem human brain specimens were obtained at autopsy from five individuals without psychiatric or neurological disorders. The average age of these subjects was $72.8 \pm 11.6$ years (range 55-86 years); three were female and two were male. The mean postmortem interval was $5.7 \pm 3.1$ hours. Brains were prepared by slicing one hemisphere into $1-\mathrm{cm}$ thick coronal slabs that were immediately frozen on dry ice.

Sections from tissue blocks containing regions of interest (striatum, prefrontal cortex, temporal cortex, primary visual cortex) were cryostat-sectioned $(20 \mu \mathrm{m})$ and were thaw-mounted onto poly-L-lysine subbed $50-x$ 75-mm microscope slides. Sections were dried and stored at $-80^{\circ} \mathrm{C}$. For this study two slides per subject per region of interest were prepared for in situ hybridization as we have previously described (Meador-Woodruff et al. 1993, 1994a, 1994b). Sections were hybridized with [ ${ }^{35} \mathrm{~S}$-labeled riboprobes for human dopamine receptor mRNA, using probes that we have described in detail in earlier studies. The $\mathrm{D}_{1}$ probe was a 396-bp fragment of the human $D_{1}$ receptor (bases 208-603) corresponding to transmembrane domains II-V, including the second cytosolic loop. The $\mathrm{D}_{2}$ receptor probe was a 446 -bp portion of the human $\mathrm{D}_{2}$ receptor (bases 10441489) and directed to the region of human $D_{2}$ receptor mRNA encoding the third intracytosolic loop and transmembrane domains VI and VII. The $\mathrm{D}_{3}$ probe was a 536-bp fragment of the human $\mathrm{D}_{3}$ receptor (bases 7271262) corresponding to transmembrane domains V-VII, including the third cytosolic loop. The $\mathrm{D}_{4}$ receptor probe was a 236-bp portion of the human $\mathrm{D}_{4}$ receptor (bases 1532-1767) and directed to the region of human $D_{4}$ receptor mRNA encoding transmembrane domain IV and the third intracytosolic loop. The $\mathrm{D}_{5}$ probe was a 900-bp fragment of the human $D_{5}$ receptor (bases 900 1799) corresponding to the third intracytosolic loop and transmembrane domains VI and VII.

To generate antisense riboprobes, $1 \mu \mathrm{g}$ of linearized DNA was labeled with $125 \mu \mathrm{Ci}$ of ${ }^{35} \mathrm{~S}$-UTP using either SP6, T3, or T7 RNA polymerase. This reaction was in a final volume of $25 \mu \mathrm{l}$ and was in the presence of $1 \mu \mathrm{l}$ each of $10 \mathrm{mM}$ ATP, $10 \mathrm{mM}$ GTP, and $10 \mathrm{mM} \mathrm{CTP;} 2 \mu \mathrm{l}$ of dithiothreitol $(0.1 \mathrm{M}) ; 5 \mu$ l of $5 \mathrm{X}$ polymerase buffer; 1 $\mu l$ of RNAse inhibitor; and $1 \mu l$ of RNA polymerase. After allowing the labeling reaction to proceed for 2 hours at $37^{\circ} \mathrm{C}$, the labeled probe was separated from unincorporated nucleotide by chromatography on a Sephadex G-50 column equilibrated with a $0.1 \mathrm{M}$ Tris- $\mathrm{HCl}(\mathrm{pH}$ 7.5) buffer containing $150 \mathrm{mM} \mathrm{NaCl}, 12.5 \mathrm{mM}$ EDTA, and $0.2 \% \mathrm{NaDodSO}_{4}$.

For in situ hybridization, slides were placed in $4 \%$ formaldehyde at room temperature for 1 hour. The sections were then rinsed in phosphate-buffered saline and placed in a solution containing proteinase $\mathrm{K}(1 \mathrm{mg} / \mathrm{ml}$ in $100 \mathrm{mM}$ Tris and $50 \mathrm{mM}$ EDTA, $\mathrm{pH} 8.0$ ) for $10 \mathrm{~min}$ utes at $37^{\circ} \mathrm{C}$. Slides were subsequently rinsed briefly with water, rinsed with $0.1 \mathrm{M}$ triethanolamine $(\mathrm{pH} 8.0)$ and treated with $0.1 \mathrm{M}$ triethanolamine $(\mathrm{pH} 8.0)$ on acetic anhydride (400:1, vol:vol) with brisk stirring for 10 minutes at room temperature. The sections were washed with $2 \times \mathrm{SSC}(300 \mathrm{mM} \mathrm{NaCl}, 30 \mathrm{mM}$ sodium citrate, $\mathrm{pH}$ 7.2) for 5 minutes at room temperature, dehydrated through graded alcohols, and air-dried.

These sections were next hybridized with the ${ }^{35} \mathrm{~S}$-labeled riboprobes overnight at $55^{\circ} \mathrm{C}$. Probes were diluted in hybridization buffer to a final concentration of $1-2 \times 10^{7} \mathrm{dpm} / \mathrm{ml}$. The hybridization buffer was $50 \%$ (vol:vol) formamide; $10 \%$ (wt:vol) dextran sulfate; $3 \times$ SSC; $50 \mathrm{mM}$ sodium phosphate, $\mathrm{pH} 7.4$; 1 X Denhardt's solution $(0.02 \%$ polyvinyl pyrrolidone, $0.02 \%$ Ficoll, $0.02 \%$ bovine serum albumin); $0.1 \mathrm{mg} / \mathrm{ml}$ yeast tRNA; and $10 \mathrm{~mm}$ dithiothreitol. A diluted probe (500 $\mu \mathrm{L}$ ) was applied to prehybridized tissue sections, covered with a glass cover slip, and placed on racks in trays above a layer of $50 \%$ formamide.

Following hybridization, the cover slips were removed. The sections were first rinsed in $2 \times$ SSC at room temperature for 5 minutes, then in RNAse A $(200 \mathrm{mg} / \mathrm{ml}$ in $10 \mathrm{mM}$ Tris, $0.5 \mathrm{M} \mathrm{NaCl}, \mathrm{pH} 8.0$ ) for 60 minutes at $37^{\circ} \mathrm{C}$, $2 \times$ SSC at room temperature for 10 minutes, $1 \times$ SSC at room temperature for 10 minutes, $0.5 \times \mathrm{SSC}$ at $55^{\circ} \mathrm{C}$ for 1 hour, and a final rinse in $0.5 \times$ SSC at room temperature. These slides were dehydrated in graded ethanols and air-dried.

The slides were placed into X-ray cassettes and apposed to Kodak XAR-5 film for 2 to 4 weeks. The film 

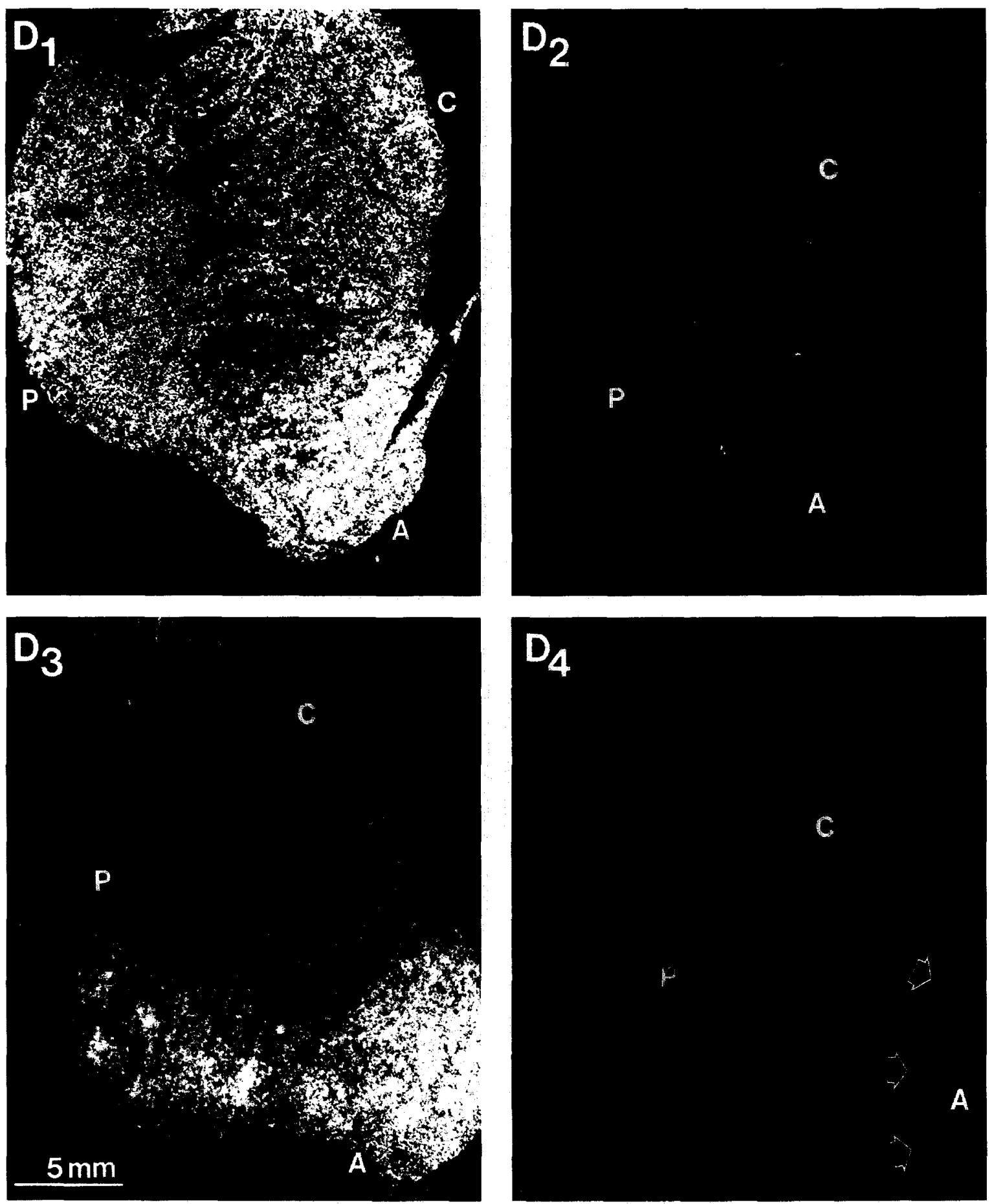

Figure 1. Dopamine receptor mRNA in the human striatum. The $\mathrm{D}_{1}$ receptor $\mathrm{mRNA}$ is rather homogeneously distributed throughout the caudate $(C)$, putamen $(P)$, and nucleus accumbens $(A)$, although there appears to be a slight enrichment in the nucleus accumbens relative to the dorsal aspect of the striatum. The $\mathrm{D}_{2}$ receptor mRNA is found in all three regions of the striatum at comparable levels of expression. The $\mathrm{D}_{3}$ receptor mRNA is present in all three regions as well, but is particularly enriched in the nucleus accumbens and the ventral aspect of the putamen. The $D_{4}$ transcript is extremely rare in the striatum, with very faint labeling occasionally seen in the medial aspect of the nucleus accumbens (arrows). D 5 receptor mRNA is not visualized in the striatum under these conditions. 
was then developed and used for image analysis using NIH Image (v1.56) on a Macintosh-based imaging system. Gray-scale values were obtained from regions of interest, corrected for tissue background, and then converted into optical density values.

Technical control studies were performed to ensure the specificity of each riboprobe, as previously described (Meador-Woodruff et al. 1993, 1994a, 1994b). Both "sense-strand" and RNAse-pretreated "antisense"labeled sections were run in parallel with "antisense"labeled sections; specific hybridization was observed only with the "antisense"-labeled probes.

\section{RESULTS}

\section{Striatal Distribution}

Dopamine receptor mRNAs are seen throughout the human striatum, but are distributed in unique patterns (Figures 1 and 2). The $D_{1}$ receptor mRNA is densely expressed in both the dorsal and ventral aspects of the striatum. This mRNA is homogeneously distributed in the caudate and putamen, with apparent equal labeling in these two subdivisions. The $D_{1}$ receptor mRNA is also expressed in the nucleus accumbens and appears to be present at slightly higher levels in this region than in the dorsal aspects of the striatum. The $\mathrm{D}_{2}$ receptor mRNA is also expressed throughout the striatum and is present at approximately equal levels in all three subdivisions. The $\mathrm{D}_{3}$ receptor mRNA is located primarily in the ventral aspect of the human striatum, with particular enrichment in the nucleus accumbens. We have also consistently noted a slight enrichment of this mRNA in the putamen compared to the caudate, associated with higher levels of labeling in discrete patches in the putamen. The $\mathrm{D}_{4}$ receptor mRNA, if present, is also at extremely low levels. We have not been able to observe this mRNA consistently within the human striatum, but occasionally it has been noted in the nucleus accumbens, particularly in the medial aspect. This needs to be interpreted with caution, however, as this low level of expression is barely above background after very long emulsion exposures. The $\mathrm{D}_{5}$ receptor mRNA is not observed in the striatum under the conditions that we have employed to date.

\section{Cortical Distribution}

The dopamine receptor mRNA is expressed throughout the human neocortex, but as seen with the striatum, this varies from mRNA to mRNA. In this report we present observations from the prefrontal, temporal, and occipital cortices.

In the prefrontal cortex the mRNAs encoding the $D_{1}$ and $D_{4}$ receptors are the most abundant, based on our observations. As shown in Figure 3 , the $D_{1}$ receptor

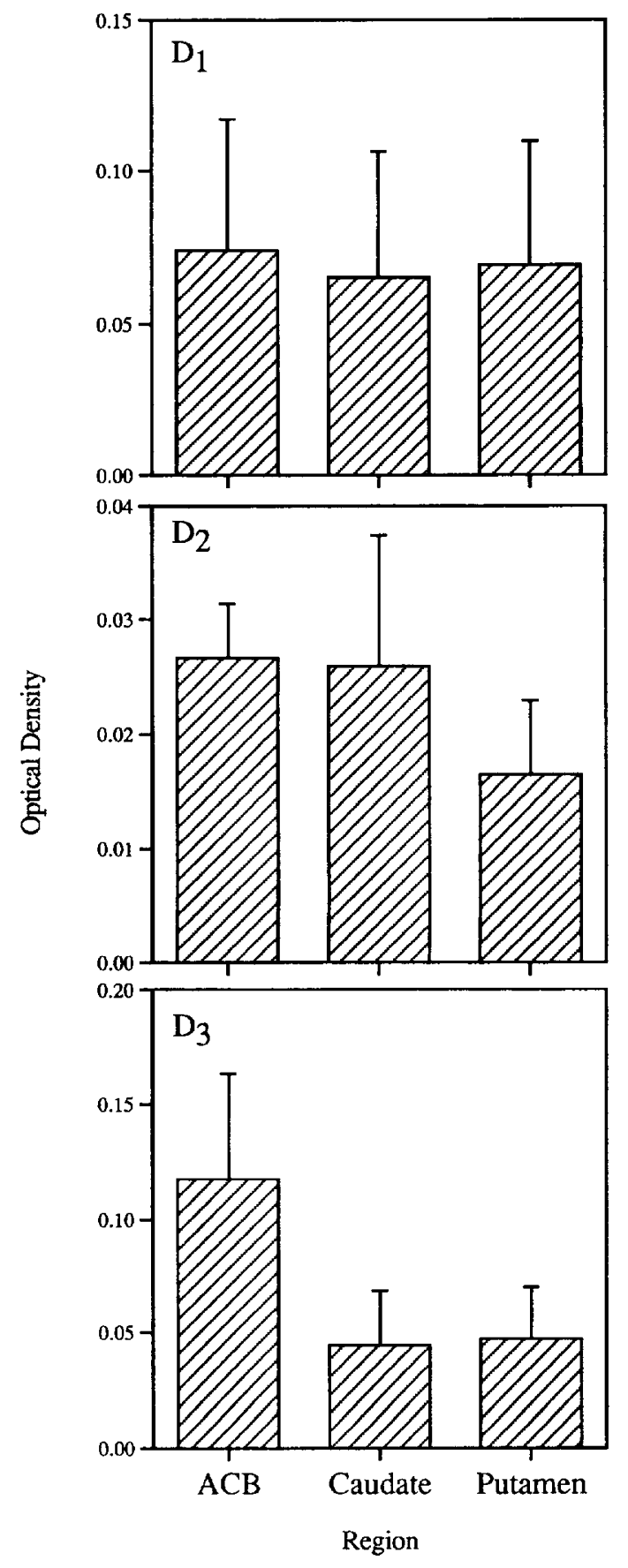

Figure 2. Quantitation of $D_{1}, D_{2}$, and $D_{3}$ receptor mRNAs in the human striatum. Optical densities were determined for the caudate, putamen, and nucleus accumbens (ACB) from the five subjects in this study. Note the generally equivalent levels of expression for $D_{1}$ and $D_{2}$ receptor mRNAs in each subdivision of the striatum, and the enrichment of the $D_{3}$ receptor mRNA in the nucleus accumbens relative to the caudate and putamen. These data are in general agreement with the qualitative images presented in Figure 1. Absolute optical density values can be compared directly only between regions for a given probe, and not across different probes. 

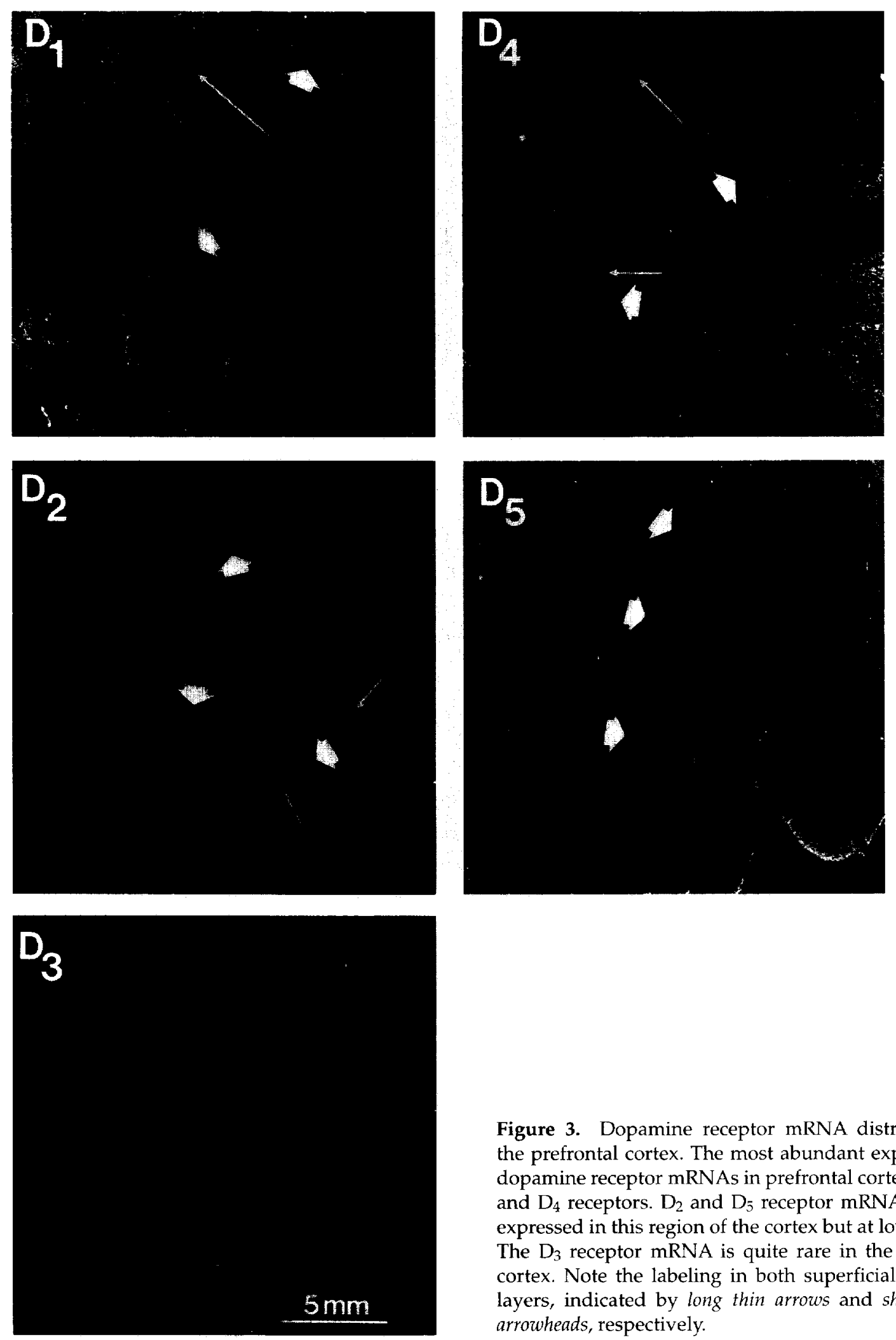

Figure 3. Dopamine receptor mRNA distribution in the prefrontal cortex. The most abundant expression of dopamine receptor $m R N A s$ in prefrontal cortex is for $D_{1}$ and $D_{4}$ receptors. $D_{2}$ and $D_{5}$ receptor mRNAs are also expressed in this region of the cortex but at lower levels. The $D_{3}$ receptor mRNA is quite rare in the prefrontal cortex. Note the labeling in both superficial and deep layers, indicated by long thin arrows and shorter thick arrowheads, respectively.

mRNA is particularly enriched in the deeper layers of the prefrontal cortex, although fainter labeling can be appreciated in more superficial layers. A similar pattern is seen for the $\mathrm{D}_{4}$ receptor $\mathrm{mRNA}$, which is observed in both superficial and deeper layers of the prefrontal neocortex. Although the gradient between laminae is not as striking as that seen for the $D_{1} m R N A$, there is an apparent enrichment of the $D_{4}$ mRNA in the deep cortex. 

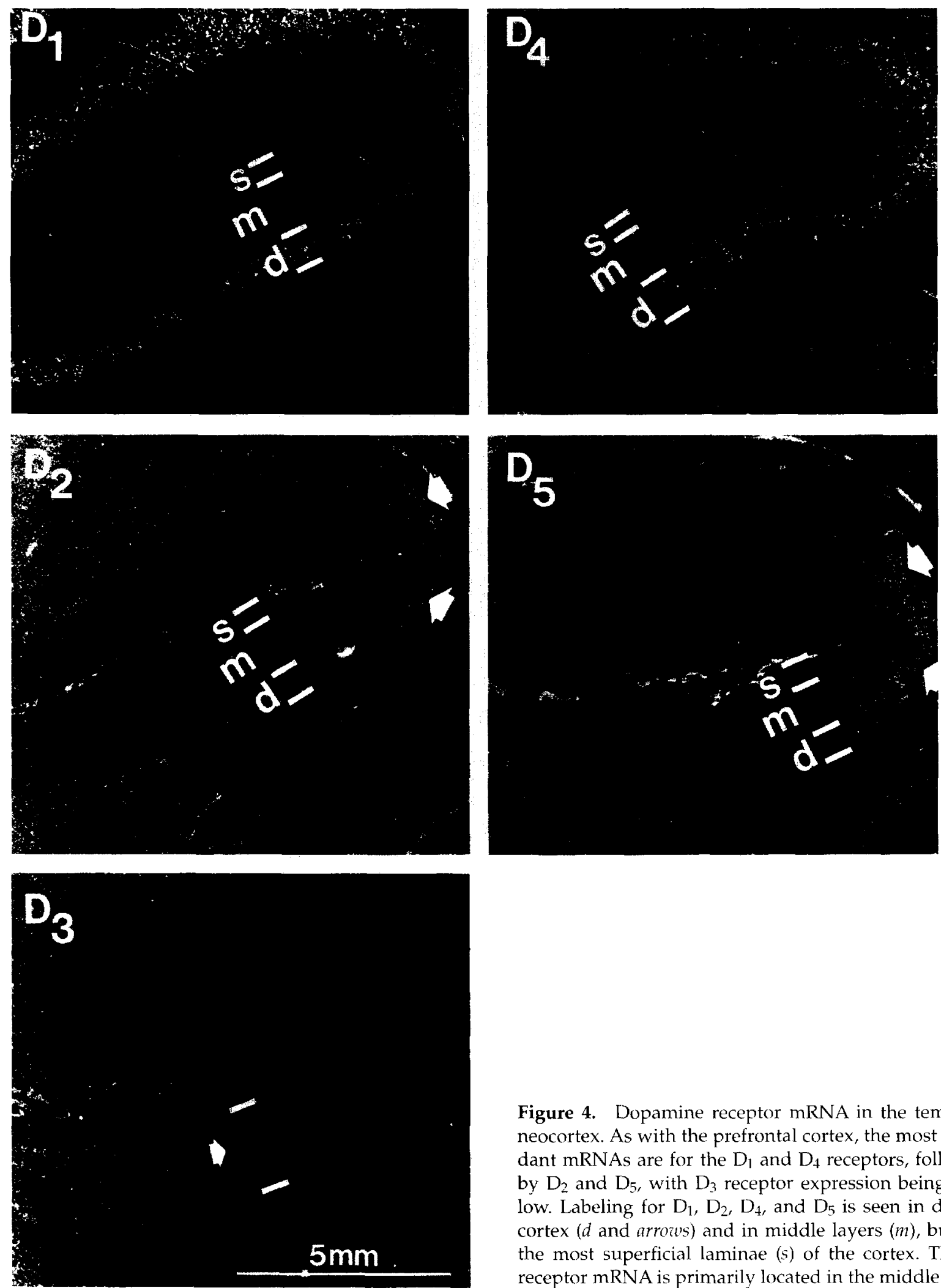

Figure 4. Dopamine receptor mRNA in the temporal neocortex. As with the prefrontal cortex, the most abundant mRNAs are for the $D_{1}$ and $D_{4}$ receptors, followed by $D_{2}$ and $D_{5}$, with $D_{3}$ receptor expression being very low. Labeling for $D_{1}, D_{2}, D_{4}$, and $D_{5}$ is seen in deeper cortex ( $d$ and arrows) and in middle layers $(m)$, but not the most superficial laminae (s) of the cortex. The $D_{3}$ receptor mRNA is primarily located in the middle zone.

The remaining three receptor mRNAs $\left(D_{2}, D_{3}\right.$, and $\left.D_{5}\right)$ are present at much lower levels than those encoding $D_{1}$ and $D_{4}$. The $D_{2}$ receptor mRNA is the most abundant of these rarer cortical transcripts and can be seen faintly in both the superficial and deep layers of this region. $D_{3}$ and $D_{5}$ receptor mRNAs are particularly rare and appear to be predominantly expressed in the deeper layers. 

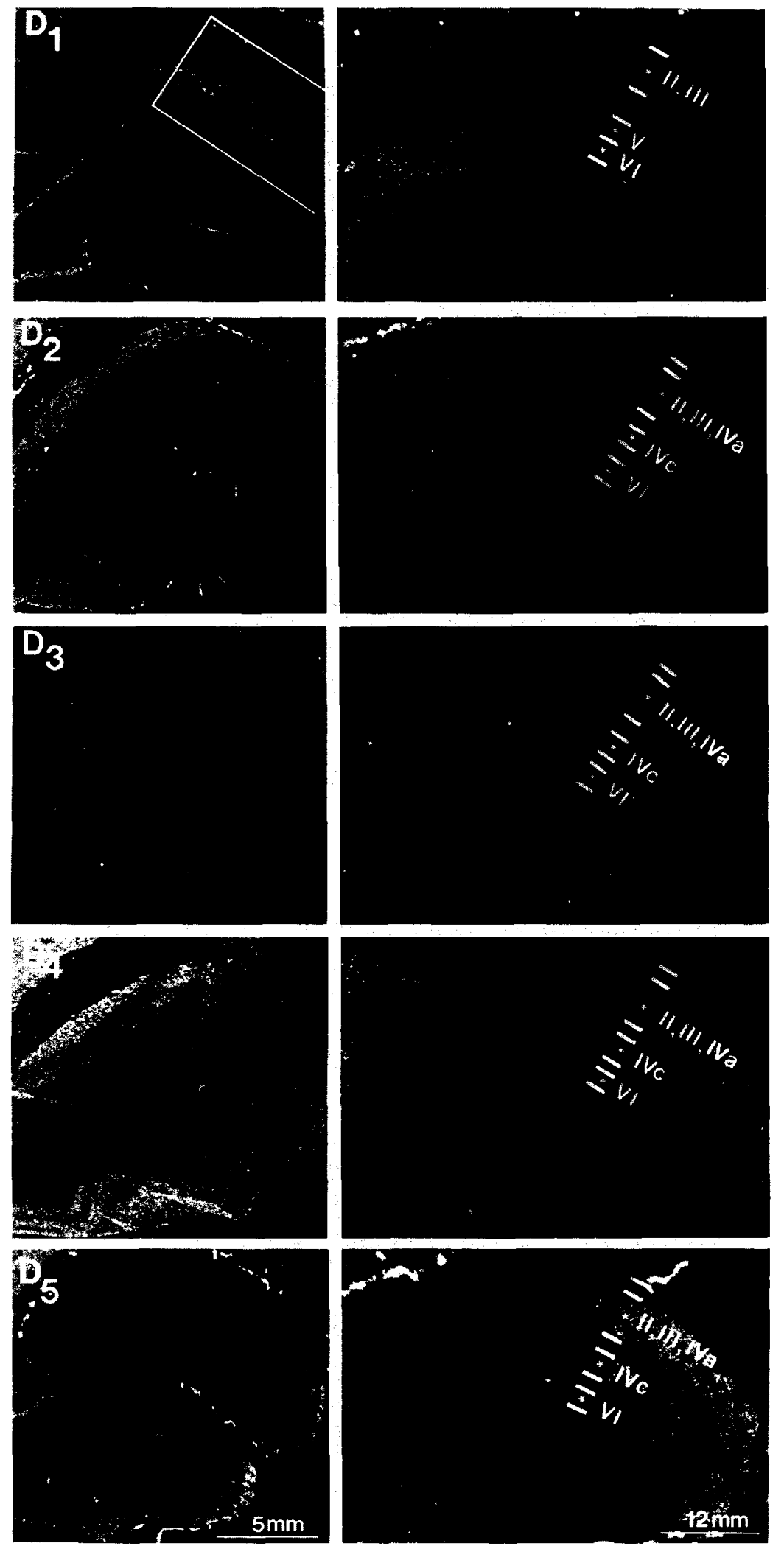

Figure 5. Dopamine receptor mRNA in the occipital cortex. At this level, the $\mathrm{D}_{1}$ receptor mRNA is the most abundant. $D_{2}$, $D_{4}$, and $D_{5}$ are relatively similar in their respective levels of expression, and, as seen in the other areas of the cortex, $\mathrm{D}_{3}$ labeling is the least abundant. The $D_{1}$ receptor mRNA is concentrated in the deeper layers (primarily layer VI). The other four transcripts are each equally distributed across three distinct zones, likely composed of layers II/III/IVa, IVC, and VI. Images at right correspond to higher-power views of the area outlined in the box in the left $D_{1}$ panel.
A similar pattern of cortical distribution is found in the temporal neocortex (Figure 4). We have previously reported our observations of the distributions of the dopamine receptor transcripts in hippocampal and related structures and noted the temporal neocortical labeling (Meador-Woodruff et al. 1994b). We expand our finding in this report. As seen in the prefrontal cortex, $D_{1}$ and $D_{4}$ receptor $m$ RNAs are the most abun- 

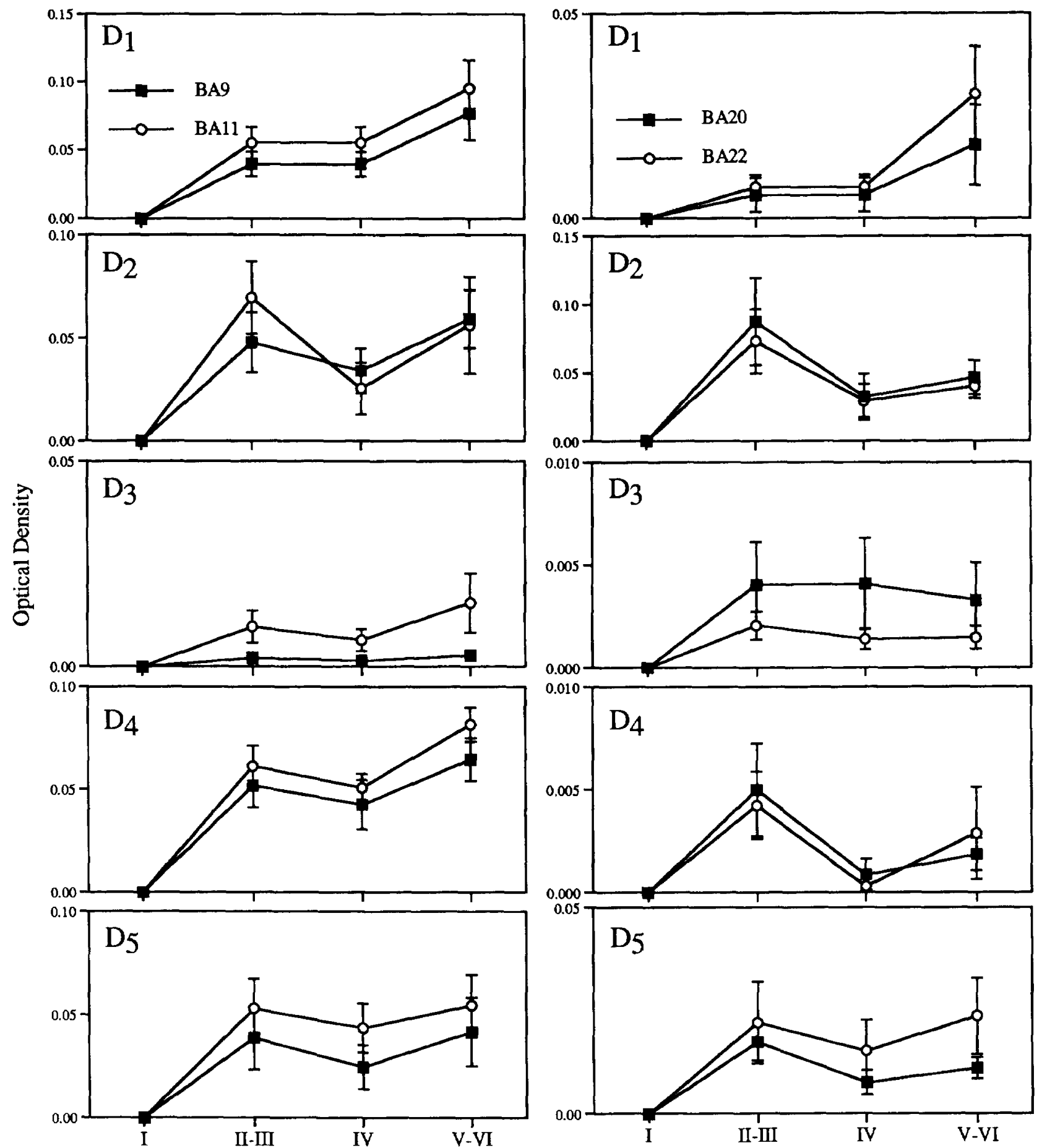

A

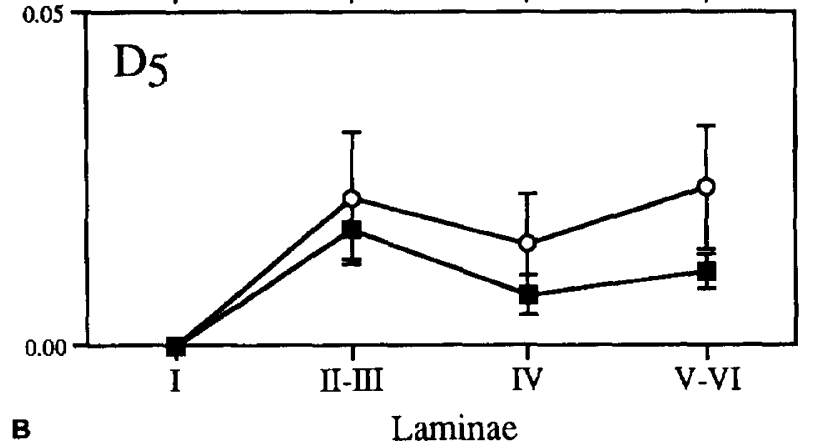

(Figure 6. continued)

dantly expressed of the dopamine receptor mRNAs in the temporal neocortex. $\mathrm{D}_{1}$ and $\mathrm{D}_{4}$ receptor mRNAs are seen in both the superficial and deeper layers of the temporal lobe cortex. There is a gradient for $\mathrm{D}_{1} \mathrm{mRNA}$, with relative enrichment in deeper layers.

Patterns for $D_{2}, D_{3}$, and $D_{5}$ mRNAs are also observed in the temporal cortex and are similar to those seen in the prefrontal cortex. The $\mathrm{D}_{2}$ receptor mRNA is again the most abundant of these three rarer mRNAs, and it is expressed in both superficial and deeper layers. $\mathrm{D}_{3}$ and $D_{5}$ receptor mRNAs are also seen in both superficial and deeper layers, although at lower levels than seen for $D_{2}$.

For the prefrontal and temporal cortices, we are 

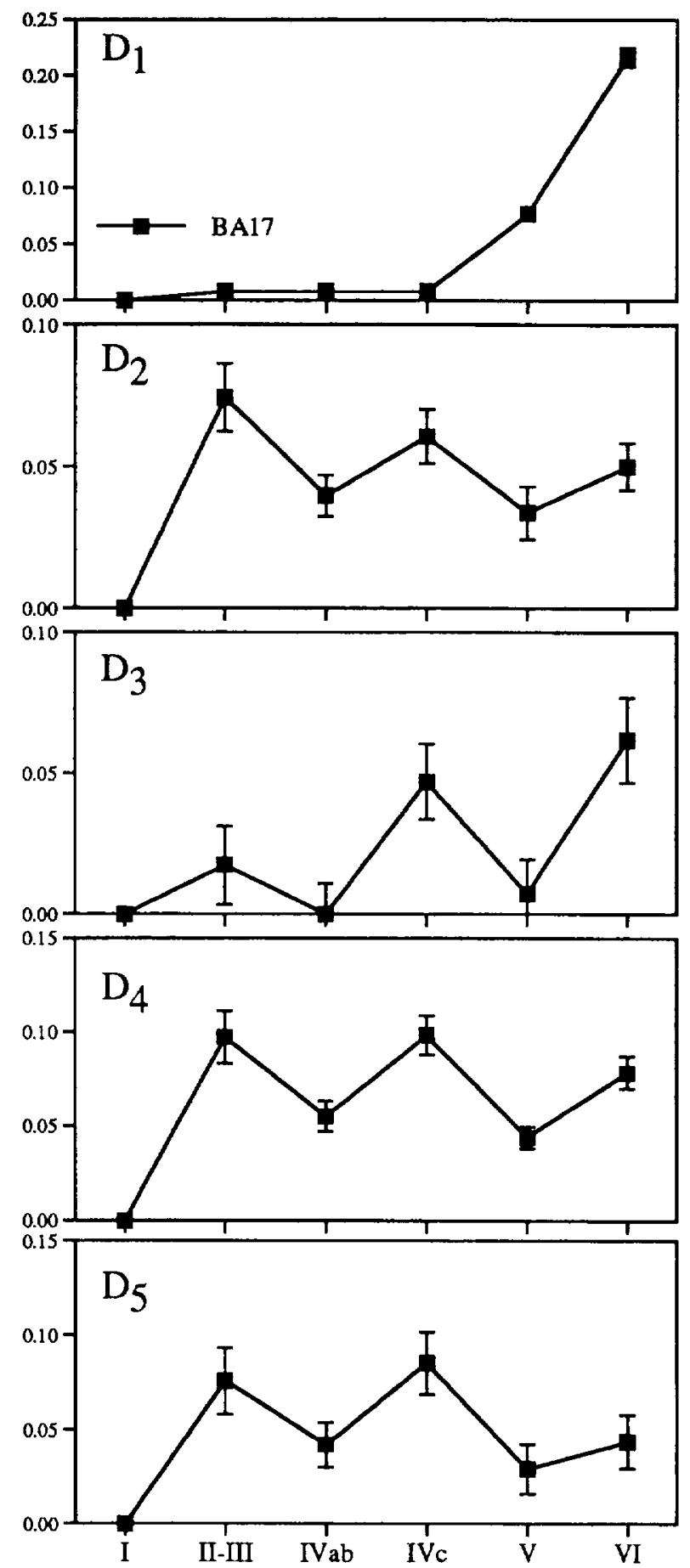

C

unable to make more definitive statements of localization of individual mRNAs to specific laminae beyond indicating that labeling was seen in superficial and/or deep layers. The conditions necessary to visualize these rare transcripts in the human cortex (frozen tissue, harsh steps to permeabilize the tissue, lengthier postmortem intervals than possible with animal experiments) result in a loss of cytoarchitectural detail. With this in mind, what we have described as "deeper lay-
Figure 6. Quantitation of dopamine receptor mRNAs in the human neocortex. Optical densities were determined in multiple cytoarchitectural regions from the five subjects in this study. (A) represents data from the prefrontal cortex (Brodmann areas 9 and 11), which parallel the images in Figure 3. (B) contains data from the temporal cortex (Brodmann areas 20 and 22), corresponding to the images in Figure 4. (C) is from the visual cortex (area 17), in general agreement with the qualitative images presented in Figure 5. See text for discussion of approximation of laminae for each region. As in the case of the striatal data presented in Figure 2, absolute optical density values can be compared only directly between laminae for a given probe, and not across different probes. ers" are likely laminae V and VI, and the more superficial layers are probably laminae II and III.

We have also examined the occipital cortex and observed a distinct lamination of mRNA labeling. Because of the striking cytoarchitecture of the primary visual cortex, we are more comfortable with our assignments of labeled layers, as shown in Figure 5 . The $\mathrm{D}_{1}$ receptor mRNA is distributed in both the superficial and deep layers with enrichment in deeper layers, as 
seen in other regions of the cortex. In the visual cortex, however, the deep labeling appears also to have a gradient, with more significant labeling in the deepest part of the deep zone (which probably reflects a higher expression of $D_{1}$ mRNA in layer VI than in layer $V$ ). Very faint labeling is also seen in a superficial zone, likely composed of laminae II and III.

The other four transcripts are seen in three discrete zones: a deep zone (apparently lamina VI), a superficial zone (apparently II, III, and IVa), as well as a welldefined middle zone that appears to correspond to layer IVc. For each probe the relative amount of mRNA labeled is about the same in each of these three zones. As in the case of the other regions of the cortex presented, the $D_{4}$ mRNA appears to be the most abundant, with $\mathrm{D}_{3}$ being the rarest. Interestingly, the levels of $\mathrm{D}_{2}$ and $D_{5}$ appear to be higher in this region than seen in the other two discussed, at least relative to the apparent density of the other transcripts.

These cortical data are presented in a more quantitative fashion in Figure 6. Cytoarchitectural regions were examined from each section, and optical densities across approximate laminae determined by image analysis following in situ hybridization. In general, these quantitative data correspond closely to the images presented in Figures 3-5. For the prefrontal cortex, both Brodmann areas 9 and 11 were surveyed. Both of these areas of the prefrontal cortex had dopamine receptor mRNA expression in both the superficial and deep layers, and the pattern of labeling for each probe was similar between both of these cytoarchitectural regions. A similar pattern was observed for the temporal cortex in the two Brodmann areas examined (areas 20 and 22) from that tissue block. Finally, in the occipital cortex (area 17), three distinct optical density peaks were observed, corresponding to the three bands apparent in Figure 5.

In addition to these five subjects, we have made similar qualitative observations in a number of other brains that we are using in other ongoing studies. We have observed similar cortical labeling in 28 subjects and this pattern of striatal expression in 36 individuals (range of ages 21-96 years).

\section{DISCUSSION}

Transcripts for the dopamine receptors are identifiable in multiple regions of the human neocortex and in the striatum, but are distributed in a heterogeneous fashion. Although the neuroanatomical distributions of these five mRNAs are well established in the rodent, less is known about their distributions in the human. Numerous lines of speculation have been advanced postulating the involvement of specific dopamine receptors (or perhaps excluding others) in psychiatric illnesses, based on the combination of their pharmacological properties and their distribution in the rat brain. It is now clear, however, that some of these receptors are differentially expressed not only across brain regions but also across species, with several discrepancies between the rat and human brain.

In the human striatum, $D_{1}, D_{2}$, and $D_{3}$ receptor mRNAs are the most abundant of the dopamine receptors. Whereas $D_{1}$ and $D_{2}$ receptor mRNAs are distributed rather equally throughout the dorsal and ventral aspects of the striatum, the $D_{3}$ receptor mRNA is expressed in a distinct manner, with prominent labeling apparent in the ventral regions, suggesting a more limbic role for the $D_{3}$ receptor. In the case of $D_{1}, D_{2}$, and $D_{3}$ receptor mRNAs, the human distributions noted here and previously reported by others (Mengod et al. 1991, 1992) are strikingly similar to the distributions of these messages in rat brain. Further, the distribution of the $D_{3}$ receptor mRNA parallels the distribution of binding sites for this receptor in the human brain (Murray et al. 1994; Herroelen et al. 1994).

Striatal $D_{4}$ mRNA receptor expression is very low in the human, at levels barely above background, and apparently restricted to the nucleus accumbens. This finding is similar to our unpublished observation of negligible $\mathrm{D}_{4}$ receptor mRNA presence (as visualized by in situ hybridization) in the rat striatum as well. There is a single report demonstrating $D_{4}$ receptor mRNA in the rat striatum using in situ hybridization that indicates that the $\mathrm{D}_{4} \mathrm{mRNA}$ is restricted to the ventral aspect of the rat striatum (O'Malley et al. 1992). Most recently Schoots et al. (1995) demonstrated that clozapine regulates the $\mathrm{D}_{4}$ receptor mRNA and binding sites in the rat striatum. In order to demonstrate the regulation of this mRNA, however, polymerase chain reaction (PCR) was used for 30 cycles to amplify the $\mathrm{D}_{4}$ mRNA for detection, suggesting that it is present at extremely low levels. The consensus on these data appears to be that the $D_{4}$ receptor mRNA may be expressed in the striata of both the rat and the human, is likely more abundant in the ventral aspect, but is probably present in both species at very low levels.

The low level of expression of the $\mathrm{D}_{4}$ receptor mRNA in the striatum is particularly intriguing given several recent reports of disproportionately higher levels of expression of putative $\mathrm{D}_{4}$ binding sites in this structure in the human and the apparent dramatic upregulation of $\mathrm{D}_{4}$ binding sites in schizophrenia. Seeman et al. (1993) recently reported a nearly sixfold increase in striatal $\mathrm{D}_{4}$ receptor binding in schizophrenic brains, using an indirect method involving subtracting $B_{\max }$ values for two different radioligands with different affinities for the $D_{2}, D_{3}$, and $D_{4}$ receptors. Of note, these data suggest that a substantial proportion (nearly half) of all " $\mathrm{D}_{2}$-like" binding in the striatum is due to $\mathrm{D}_{4}$ sites. Using a similar strategy Murray and coworkers (1995) have replicated this finding, but the magnitude of 

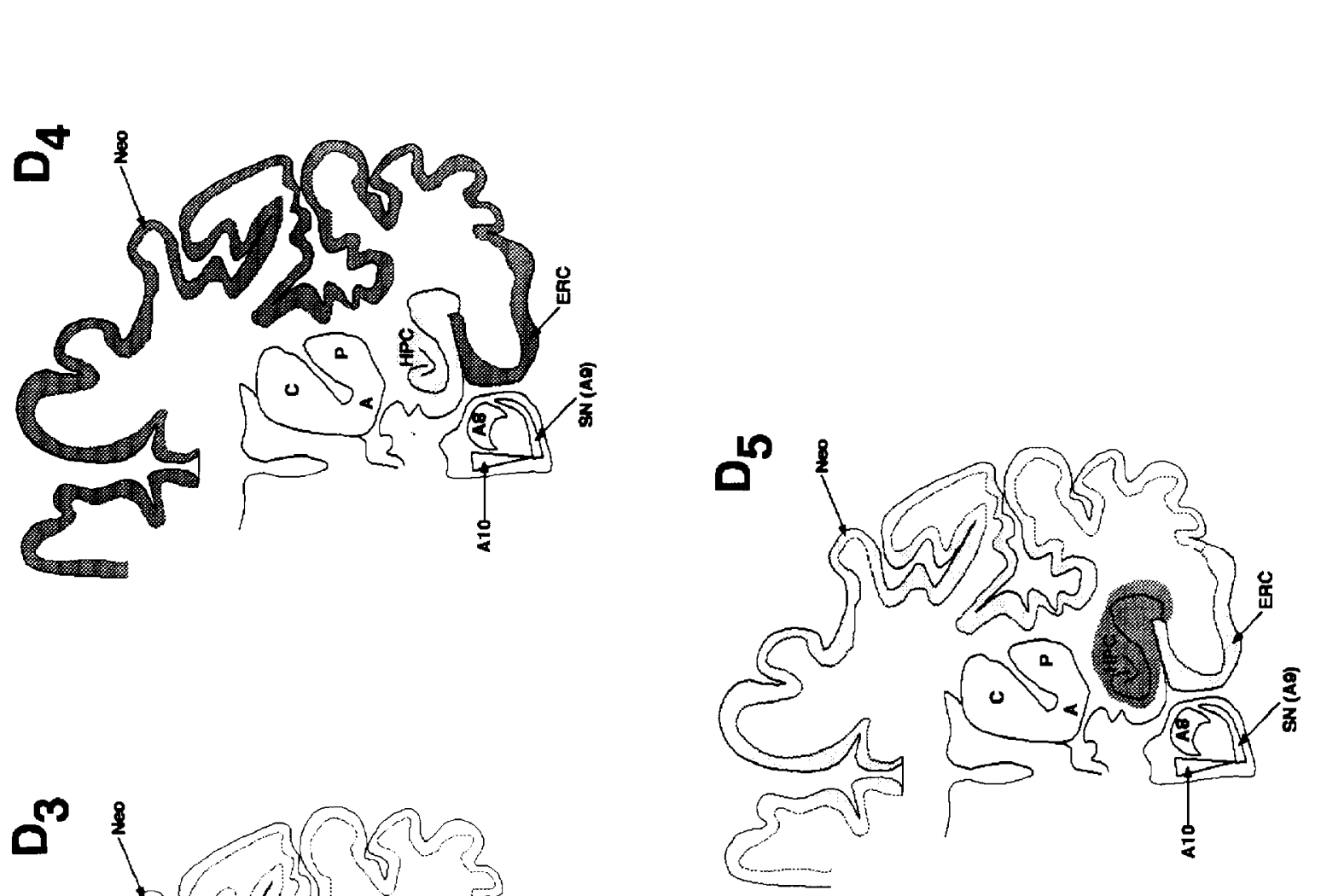

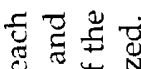

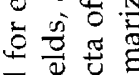

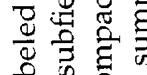

过

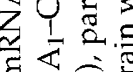

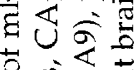

节究芯

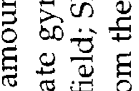

至苛

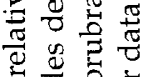

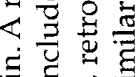

$\Xi \underset{\sigma}{\infty}$

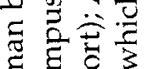

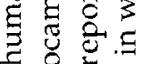

定

$\Xi \exists . \Xi$

岩重要
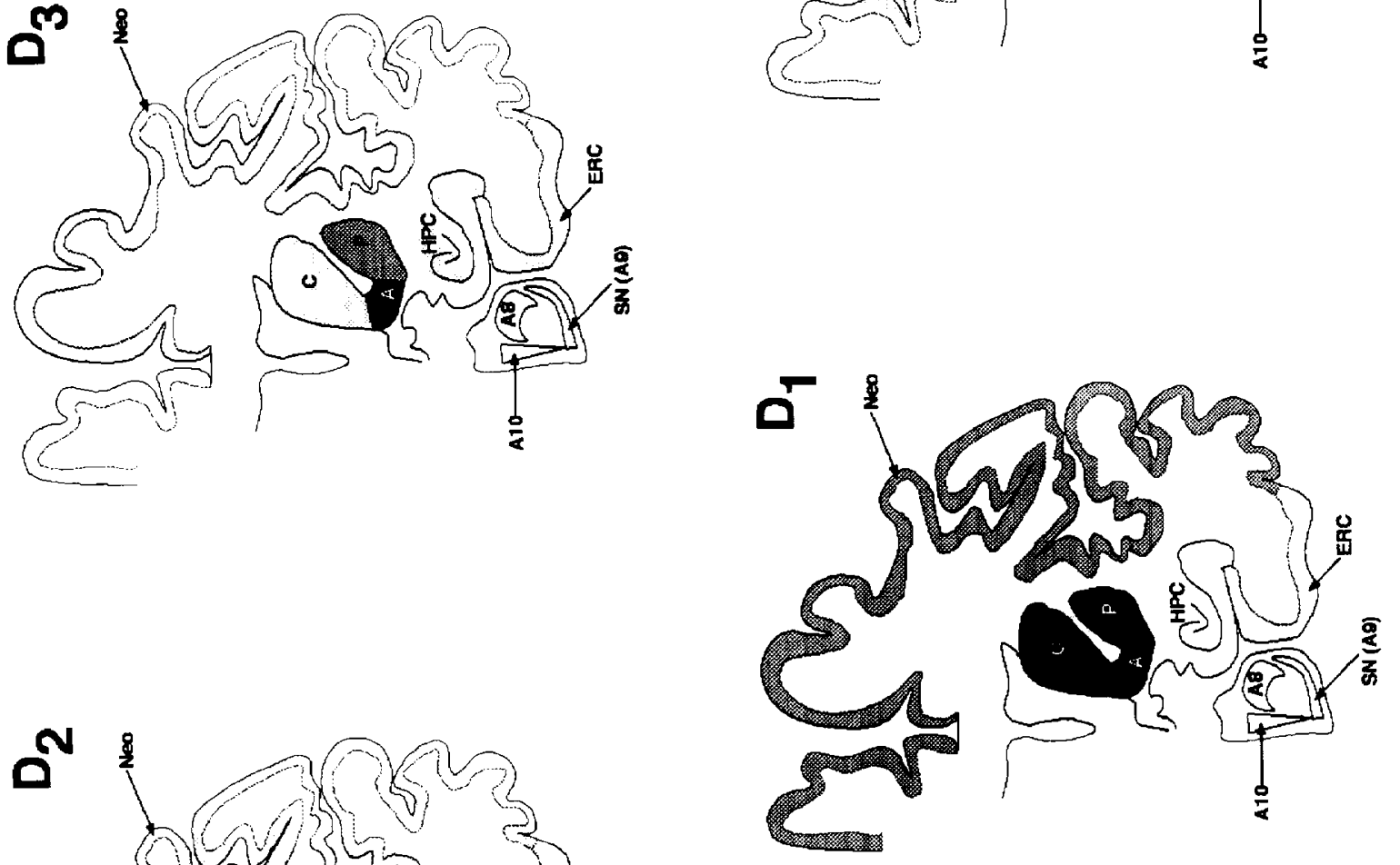

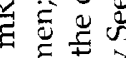

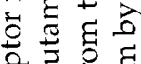

욜로

近号

过鸪坖

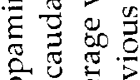

ठิ

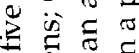

ङ

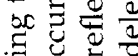

8 o 00

ప

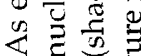

\& $x$

文苛品

苛记

峁气

㐘造焉

至藏

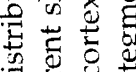

ठ

氙氜

廿

空至

준

츠눙

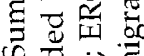

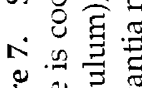

‡ 
change was not nearly as dramatic. These reports need to be interpreted with caution, however, as not all groups have been able to demonstrate $\mathrm{D}_{4}$-like binding in human striatum using these subtraction techniques (Reynolds et al. 1994).

If the Seeman and Murray results are correct, however, there appears to be a striking dissociation between the $\mathrm{D}_{4}$ mRNA and $\mathrm{D}_{4}$ binding sites in the striatum. In both the rat and the human very low levels of apparent mRNA expression appear to result in very high levels of $\mathrm{D}_{4}$ binding sites (perhaps as much as half of all $\mathrm{D}_{2}$-like sites in the striatum). The efficiency of translation of this particular mRNA may well be extraordinarily high. However, the necessary rate would appear to be unprecedented in receptor neurobiology. A more likely interpretation of these data is that the $D_{4}$ receptors expressed in striatum are encoded elsewhere and transported to the striatum; the mRNA is seen solely over the cell bodies of cells encoding the given receptor, whereas the final receptor protein is inserted into the membrane over the cell body as well as on distal processes. Given the abundant expression of $\mathrm{D}_{4}$ receptor mRNA in deeper layers of the neocortex, it appears likely that striatal $D_{4}$ binding sites are encoded in the cortex. It is probable that striatal $\mathrm{D}_{4}$ receptors are encoded by glutamatergic cells in the cortex projecting to the striatum; the striatal $D_{4}$ receptors would then be presynaptic receptors on glutamatergic efferents.

An alternative explanation would be that striatal $D_{4}$ receptors are encoded in the dopamine-containing midbrain nuclei (primarily the substantia nigra and the ventral tegmental area), represent dopamine receptors that are located presynaptically on dopaminergic cell processes, and thus serve a role as dopamine autoreceptors. This possibility is much less likely: we have previously reported that dopamine autoreceptors in the human appear to be restricted to the $D_{2}$ and $D_{3}$ receptors, as we are not able to visualize the $D_{4}$ receptor mRNA in the human midbrain (Meador-Woodruff et al. 1994a).

We have been unable to demonstrate the existence of the $D_{5}$ receptor mRNA in the striatum in the rat or in the human brain. Interestingly, however, we have visualized low levels of $D_{5}$ receptor transcript in the brain of the old-world monkey (Beischlag et al. 1995), as has another group (Huntley et al. 1992).

The cortical data from the present study are considerably different from what has been previously reported in the rat brain. In general, $D_{1}, D_{2}, D_{3}$, and $D_{4}$ receptor mRNAs have all been seen in the rat neocortex, but at very low levels of expression (Meador-Woodruff 1994; Meador-Woodruff et al. 1994c, 1995). The $\mathrm{D}_{5}$ receptor mRNA has not been found in the rat cortex. In the human all five of these mRNAs are expressed in the cortex, and at apparently much higher levels than in the rat. As seen in the rat, the $D_{1}$ receptor mRNA is the most abundant dopamine receptor mRNA in the human cortex, and it is primarily expressed in the deeper layers. The other four transcripts are expressed in both the superficial and deep layers in the human. Although the distributions of the $D_{2}$ receptor mRNA in the rat and human appear similar, the expression of the $\mathrm{D}_{3}, \mathrm{D}_{4}$, and $D_{5}$ receptors are notably different.

The $D_{3}$ receptor mRNA is clearly the rarest of these transcripts in the human neocortex, expressed at relatively lower levels in the human than in the rat. On the other hand, the $\mathrm{D}_{4}$ receptor mRNA is enriched in the human cortex, and in some regions it may be the predominant form of "D2-like" (e.g., $\mathrm{D}_{2}, \mathrm{D}_{3}$, and $\mathrm{D}_{4}$ ) mRNA expression. The $D_{5}$ receptor $m R N A$ has a pattern similar to that of the $D_{2}$ receptor, unusual and unexpected given its lack of cortical distribution in the rat. These results in the human cortex are similar to what has been previously reported in the monkey and human motor cortex for $D_{1}, D_{2}$, and $D_{5}$ receptor mRNAs (Huntley et al. 1992). Transcripts for all five of the dopamine receptors are expressed in multiple regions of the human neocortex and thus appear to be substrates for encoding cortical $D_{1}$ - and $D_{2}$-like receptor binding.

These data add to our earlier reports of the distribution of dopamine receptors in the human medial temporal lobe (particularly the hippocampus) (MeadorWoodruff et al. 1994b) and midbrain (Meador-Woodruff et al. 1994a). We have attempted in Figure 7 to summarize the data in the current report, these previous papers, and the rest of the literature that has been cited. This summary figure reflects the current state of understanding of the distributions of these five transcripts in the human brain.

In addition to their pharmacological properties, the neuroanatomical pattern of expression of the subtypes of dopamine receptors is an important determinant of the net activity of the brain dopamine systems. This anatomy has been most extensively studied in the rat, but more recent work in the human brain has revealed some significant differences between human and rat neurochemical anatomy. These differences are likely important in understanding various aspects of the manifestations and treatment of disorders of dopaminergic neurotransmission, particularly schizophrenia.

\section{ACKNOWLEDGMENTS}

This work was supported by grants from NIMH (MH53327 and MH00818 to JHMW and MH42251 to SJW) and from the Stanley Foundation (to JHMW). Dopamine receptor clones used in this study were provided by the following individuals, to whom the authors express their appreciation: human $D_{1}, D_{2}$, and $D_{5}$, David K. Grandy, Ph.D., and Olivier Civelli, Ph.D.; human $\mathrm{D}_{3}$, Robert A. Horlick, Ph.D.; and human $\mathrm{D}_{4}$, Hubert H. M. Van Tol, Ph.D. 


\section{REFERENCES}

Beischlag TV, Marchese A, Meador-Woodruff JH, Damask SP, O'Dowd BF, Tyndale RF, Van Tol HHM. Seeman P, Niznik HB (1995): The human dopamine $D_{5}$ receptor gene: Cloning and characterization of the 5 -flanking and promoter region. Biochemistry 34:5960-5970

Dearry A, Gingrich JA, Falardeau P, Freameau RT Jr, Bates MD, Caron M (1990): Molecular cloning and expression of the gene for a human $D_{1}$ receptor. Nature 347:72-75

Giros B, Martres M-P, Sokoloff P, Schwartz J-C (1990): Clonage du gène du recepteur dopaminergique $D_{3}$ humain et identification de son chromosome. Acad Sci Paris 311:501-508

Grandy DK, Marchionni MA, Makam H, Stofko RE, Alfano M, Frothingham L, Fischer JB, Burke-Howie KJ, Bunzow JR, Server AC, Civelli O (1989): Cloning of the CDNA and gene for a human $D_{2}$ dopamine receptor. Proc Natl Acad Sci U S A 86:9762-9766

Herroelen L, De Backer JP, Wilczak N, Flamez A, Vauquelin G, De Keyser J (1994): Autoradiographic distribution of $\mathrm{D}_{3}$-type dopamine receptors in human brain using $\left[{ }^{3} \mathrm{H}\right] 7$-hydroxy-N,N,-di-n-propyl-2-aminotetralin. Brain Res 648:222-228

Huntley GW, Morrison JH, Prikhozhan A, Sealfon SC (1992): Localization of multiple dopamine receptor subtype mRNAs in human and monkey motor cortex and striatum. Brain Res Mol Brain Res 15:181-188

Meador-Woodruff JH (1994): Lpdate on dopamine receptors. Ann Clin Psychiatry 6:79-90

Meador-Woodruff JH (1995): Neuroanatomy of dopamine receptor gene expression: Potential substrates for neuropsychiatric illness. Clin Neuropharmacol 18:S14-S24

Meador-Woodruff JH, Little KY, Damask SP, Mansour A, Watson SJ (1993): Effects of cocaine on dopamine receptor gene expression: A study in the postmortem human brain. Biol Psychiatr 34:348-355

Meador-Woodruff JH, Damask SP, Watson SJ Jr (1994a): Differential expression of autoreceptors in the ascending dopamine systems of the human brain. Proc Natl Acad Sci U S A 91:8297-8301

Meador-Woodruff JH, Grandy DK, Van Tol HHM, Damask SP, Little KY, Civelli O, Watson SJ Jr (1994b): Dopamine receptor gene expression in the human medial temporal lobe. Neuropsychopharmacology 10:239-247

Meador-Woodruff JH, Mansour A, Saul J, Watson SJ (1994c): Neuroanatomical distribution of dopamine receptor messenger RNAs. In Niznik HB (ed), Dopamine receptors and transporters: Pharmacology, Structure and function. New York, Dekker pp 401-415

Mengod G, Vilaró MT, Niznik HB, Sunahara RK, Seeman P,
O'Dowd BF, Palacios JM (1991): Visualization of a dopamine $D_{1}$ receptor $m R N a$ in human and rat brain. Brain Res Mol Brain Res 10:185-191

Mengod G, Vilaró MT, Landwehrmeyer GB, Martinez-Mir MI, Niznik HB, Sunahara RK, Seeman P, O'Dowd BF, Probst A, Palacios JM (1992): Visualizations of dopamine $D_{1}, D_{2}$, and $D_{3}$ receptor $m R N A s$ in human and rat brain. Neurochem Int Suppl 20:33S-43S

Murray AM, Ryoo HL, Gurevich E, Joyce JN (1994): Localization of dopamine $D_{3}$ receptors so mesolimbic and $D_{2}$ receptors to mesostriatal regions of human forebrain. Proc Natl Acad Sci U S A 91:11271-11275

Murray AM, Hyde TM, Knable MB, Herman MM, Bigelow LB, Carter JM, Weinberger DR, Kleinman JE (1995): Distribution of putative $\mathrm{D}_{4}$ dopamine receptors in postmortem striatum from patients with schizophrenia. J Neurosci 15:2186-2191

O'Malley KL, Harmon S, Tang L, Todd RD (1992): The rat dopamine $\mathrm{D}_{4}$ receptor: Sequence, gene structure, and demonstration of expression in the cardiovascular system. New Biol 4:137-146

Reynolds GP, Mason SL (1994): Are striatal dopamine $\mathrm{D}_{4}$ receptors increased in schizophrenia? J Neurochem 63: $1576-1577$

Schoots O, Seeman P, Guan H-C, Paterson AD, Van Tol HHM (1995): Long-term haloperidol elevates dopamine $\mathrm{D}_{4}$ receptors by 2 -fold in rats. Eur J Pharmacol Mol 289:6772

Seeman P (1992): Dopamine receptor sequences: Therapeutic levels of neuroleptics occupy $D_{2}$ receptors, clozapine occupies $\mathrm{D}_{4}$. Neuropsychopharmacology 7:261-284

Seeman P, Guan H-C, Van Tol HHM (1993): Dopamine $D_{4}$ receptors elevated in schizophrenia. Nature 365:441-445

Sunahara RK, Niznik HB, Weiner DM, Stormann TM, Brann MR, Kennedy JL, Gelernter JE, Rozmahel R, Yang Y, Israel Y, Seeman P, O'Dowd BF (1990): Human dopamine $D_{1}$ receptor encoded by an intronless gene on chromosome 5. Nature 347:80-83

Sunahara RK, Guan H-C, O'Dowd BF, Seeman P, Laurier LG, Ng G, George SR, Torchia J, Van Tol HHM, Niznik HB (1991): Cloning of the gene for a human dopamine $D_{5}$ receptor with higher affinity for dopamine than $D_{1}$. Nature 350:614-619

Van Tol HHM, Bunzow JR, Guan HC, Sunahara RK, Seeman P, Niznik HB, Civelli O (1991): Cloning of the gene for a human dopamine $D_{4}$ receptor with high affinity for the antipsychotic clozapine. Nature 350:610-614

Zhou Q-Y, Grandy DK, Thambi L, Kushner JA, Van Tol HHM, Cone R, Pribnow D, Salon J, Bunzow JR, Civelli $O$ (1990): Cloning and expression of human and rat $D_{1}$ dopamine receptors. Nature 347:76-80 